\title{
エンドセリンによる骨格筋での インスリン抵抗性の発症機序
}

\author{
堀之内孝広 ${ }^{1)}$, 真崎 雄一 $^{1 \text { ) }}$, 寺田 晃士 ${ }^{2)}$, 三輪 聡一 $^{1)}$
}

要約：インスリン抵抗性とは, 骨格筋, 脂肪細胞, 肝 臓などで，インスリンに対する感受性が低下した病態 を指す。インスリン抵抗性では, インスリンによる正 常なグルコース（糖）代謝が障害されているため, 2 型糖尿病の発症につながる。近年, 社会の高龄化や 都市化に伴う食生活の変化や運動量の減少によって, 2 型糖尿病患者が急増していることから，インスリン 抵抗性の病態基盤の解明は，焦眉の課題となっている. グルコースは, 脳, 骨格筋, 脂肪, 内蔵などで代謝・ 利用されているが, 全身のグルコース利用に対する各 組織の寄与率は大きく異なる。健常者の骨格筋におけ るグルコース利用率は，全身の $70 \%$ を占めているが, 2 型糖尿病患者では, 骨格筋におけるグルコース利用 率が特異的に半減している。このことは, 骨格筋にお けるインスリン抵抗性が 2 型糖尿病の発症に関与して いる可能性を示唆している，血管収縮性・炎症性ペプ チドであるエンドセリン-1（ET-1）は，インスリン抵 抗性を惹起することが報告されているが, その詳細な 発症機序は不明である。本研究では, ラット L6 筋管 細胞を用いて，インスリンシグナルに対する ET-1の 作用を薬理学的に解析した。 L6 筋管細胞において, インスリンは, PI3 キナーゼの活性化を介して, Aktの リン酸化とグルコースの取り达みを促進した. ET-1 は，インスリンによる Aktリン酸化とグルコース取り 込みを抑制し, この ET-1の抑制作用は, 選択的エンド セリン $\mathrm{A}$ 型受容体 $\left(\mathrm{ET}_{\mathrm{A}} \mathrm{R}\right)$ 遮断薬や選択的 $\mathrm{G}_{\mathrm{q} / 11}$ タン パク質阻害薬の前処理及び siRNAによる内在性 G夕ン パク質共役型受容体キナーゼ 2 (GRK2) の発現抑制に よって解除された. また, ET-1 は, Akt と GRK2 との 相互作用を増強した。 以上の結果から, L6 筋管細胞 において， $\mathrm{ET}_{\mathrm{A}} \mathrm{R}$ 及び GRK2 が，ET-1 によるインスリ ンシグナルの抑制に関与していると考えられた。

\section{1.はじめに}

エンドセリン-1（ET-1）は，血管内皮細胞で産生さ れる血管収縮性・炎症性ペプチドであり(1)，糖尿病 （2）や肺高血圧症 (3-4), 動脈硬化症 (2) といった様々 な疾患の発症・進展に関与している。これらの疾患を 有する患者において, 血中 ET-1 濃度の上昇が認めら れており (5-8), 過剩に産生されたET-1 は, ETA型受 容体 $\left(\mathrm{ET}_{\mathrm{A}} \mathrm{R}\right)$ を介した持続性の血管収縮 (9) や $\mathrm{ET}_{\mathrm{B}} \mathrm{R}$ のダウンレギュレーションによる血管内皮機能不全 (10)，インスリン抵抗性(11-12) を惹起する.

一般に, インスリン抵抗性は, インスリン受容体 (InsR) が発現している組織において, InsRを介した シグナル伝達が障害され，インスリンに対する感受性 が低下した状態を指す(13)，インスリンは，血糖降下 作用を有しており，骨格筋や心筋，脂肪組織において， グルコース（ブドウ糖）の細胞内取り込みを促進し, また, 肝臓において, 糖新生を抑制する。骨格筋, 心 筋，脂肪組織には，グルコーストランスポーター 4 （GLUT4）が発現しており，インスリンはGLUT4 を介 したグルコース取り込みを促進する。これらの臓器に おけるグルコース利用率は大きく異なっており, 健常 者の場合, 全身のグルコース利用のおよそ70\%を骨格 筋が担っている (14)。ところが，2 型糖尿病患者では， 健常者と比較して, 骨格筋におけるグルコース利用率 が特異的に半減していることが報告されている(14). インスリンによる骨格筋へのグルコース取り込みは, 細胞膜の GLUT4 発現量によって調節されているが, 健常者と 2 型糖尿病患者との間で，骨格筋における GLUT4 タンパク質発現量に有意な差は認められてい ない(15)。従って，2型糖尿病患者における骨格筋で

キーワード：エンドセリン，インスリン抵抗性，Gタンパク質共役型受容体キナーゼ 2 , グルコーストランスポーター 4 , 骨格筋細胞

1) 北海道大学 大学院医学研究院 薬理学講座 細胞薬理学教室（ $\mathrm{T} 060-8638$ 北海道札幌市北区北 15 条西 7 丁目）

2) 滋賀医科大学 生化学・分子生物学講座 分子生理化学部門（下520-2192 滋賀県大津市瀬田月輪町）

E-mail: horinouc@med.hokudai.ac.jp＼cjkstart原稿受領日：2017 年 12 月 18 日，依頼原稿 
のグルコース利用率の低下は，グルコース輸送を担う GLUT4の発現量減少によるものではなく, 骨格筋に おけるインスリン抵抗性の発症に起因しているものと 考えられている.

本稿では，著者らが見出した骨格筋細胞に発現する $\mathrm{ET}_{\mathrm{A}} \mathrm{R}$ を介したインスリン抵抗性の発症機序 (13) につ いて, 解説する.

\section{2. 骨格筋細胞におけるインスリンのグルコース 取り込み促進作用の分子基盤}

骨格筋において, インスリンは, 細胞内の GLUT4 貯 蔵小胞に局在する GLUT4 の形質膜移行を促進させる ことによって，グルコースの細胞内取り込みを増加さ せる (16). InsR は, 2 つの $\alpha$ サブユニットと 2 つの $\beta$ サブユニットで構成される 4 量体であり, インスリン が, InsRの $\alpha$ サブユニットに結合すると, InsRの $\beta$ サ ブユニットに内在するチロシンキナーゼが活性化され て，インスリン受容体基質（IRS）のチロシン残基がリ ン酸化される. ホスファチジルイノシトール 3 キナー ゼ (PI3K) は, IRSのリン酸化チロシンヘリクルート され, 活性化される. 活性化された PI3K は, ホスファ チジルイノシトール-4,5-二リン酸をホスファチジルイ ノシトール-3,4,5-三リン酸に変換し, その結果, ホスホ イノシチド依存性プロテインキナーゼ 1 (PDK1) と Akt が形質膜へリクルートされる (16-17). 形質膜へ移 行したAktは, PDK1 による 308 番目のトレオニン残 基 $\left(\mathrm{Thr}^{308}\right)$ のリン酸化及び哺乳類ラパマイシン標的夕 ンパク質による 473 番目のセリン残基 $\left(\operatorname{Ser}^{473}\right)$ のリン 酸化を受けて活性化される（16,18-19）。活性化された Akt は, Rab GTPase 活性化タンパク質である AS160 を リン酸化することによって, GLUT4 の形質膜移行を促 進する(16). 即ち, 骨格筋におけるAktの活性化は, イ ンスリンによるGLUT4 を介したグルコース取り込み 促進において, 必要不可欠な細胞内イベントである.

\section{3. エンドセリンによるインスリン抵抗性の発 症に関する従来の知見}

骨格筋における毛細血管の収縮や拡張能障害は, 骨 格筋へのインスリンやグルコースの送達を低下させる ため, 骨格筋でのインスリン抵抗性の発症に関与する (20-21). 従来, ET-1による骨格筋でのインスリン抵 抗性の発症は, ET-1の血管収縮作用に起因する骨格 筋へのインスリン送達量の減少によるものと考えられ てきたが，その一方で，骨格筋に対する ET-1の直接的 なインスリンシグナル抑制作用も報告されている。例 えば, 健常者に ET-1 を投与した場合, 骨格筋での血流
低下は認められないものの，骨格筋におけるインスリ ン誘発性グルコース取り达みが減少することが報告さ れている (22)。また，ヒト骨格筋細胞において，ET-1 は，インスリンによって促進されるAktのリン酸化と グルコース取り达みを抑制する (11) .これらの知見は, ET-1 が骨格筋に直接作用して，インスリン抵抗性を 惹起することを示唆しているが, ET-1 によるインス リンシグナルの抑制機序については不明な点が多い.

\section{4. $\mathrm{G}$ タンパク質共役型受容体キナーゼ 2 による インスリンシグナルの抑制機序}

$\mathrm{G}$ タンパク質共役型受容体キナーゼ 2（GRK2）は, 当初, 活性薬が結合した $\mathrm{G}$ タンパク質共役型受容体 (GPCR) を特異的にリン酸化することによって, GPCRの脱感作を引き起こすセリン／トレオニンキ ナーゼとして同定された(23).ところが, 近年, GRK2 が，シグナル分子とのタンパク質ータンパク質 相互作用を介して，リン酸化非依存性に，受容体シグ ナルを負に制御していることが明らかにされている (24)，例えば，脂肪細胞において，InsR刺激による $\mathrm{G}_{\mathrm{q} / 11}$ タンパク質の $\alpha$ サブユニット $\left(\mathrm{G}_{\mathrm{q} / 11 \alpha}\right)$ のリン酸化 は，GLUT4 を介したグルコース取り込みを促進させる が, $\mathrm{GRK} 2$ は $\mathrm{G}_{\mathrm{q} / 11 \alpha}$ タンパク質と結合することによっ て, InsR シグナルを抑制する $(12,25)$. また, 正常な類 洞内皮細胞において, $\mathrm{ET}_{\mathrm{B}} \mathrm{R}$ 刺激による $\mathrm{G}$ タンパク質の $\beta \gamma$ サブユニット $\left(\mathrm{G}_{\beta \gamma}\right)$ を介した Aktのリン酸化は, 内 皮型一酸化窒素合成酵素の活性化を介して, 一酸化窒 素産生を促進させるが, 門脈圧立進により傷害を受け た類洞内皮細胞においては，正常時よりも発現上昇し た GRK2 が, Aktや $\mathrm{G}_{\beta \gamma}$ と結合することによって, $\mathrm{ET}_{\mathrm{B}} \mathrm{R}$ シグナルを抑制する(26). なお, $\mathrm{ET}_{\mathrm{B}} \mathrm{R}$ から解離した $\mathrm{G}_{\beta \gamma}$ と $\mathrm{GRK} 2$ とのタンパク質ータンパク質相互作用は, GRK2 の形質膜移行を促進することから, 形質膜へ移 行した $\mathrm{GRK} 2$ による $\mathrm{ET}_{\mathrm{B}} \mathrm{R}$ のリン酸化も, $\mathrm{ET}_{\mathrm{B}} \mathrm{R}$ シグナ ルの抑制に関与すると考えられている $(26)$.

これらの知見から，著者らは，骨格筋において， ET-1 が, GRK2 の形質膜移行を促進し, その結果, GRK2 と Aktとのタンパク質ータンパク質相互作用の 増強, 即ち, Akt シグナルの抑制を引き起こすことに よって, インスリン抵抗性が惹起されるという作業仮 説を立て，以下の実験に着手した。

\section{5. 筋芽細胞から筋管細胞への分化誘導}

ラット L6 骨格筋細胞株は, グルコース輸送や筋形 成の研究において, 広く用いられている。 L6筋芽細 胞は, 自発的に筋管細胞へ分化する能力を有している 
が $(27)$, 高濃度（例. 10\%）のウシ胎児血清（FBS） が添加されている液体培地中では, FBS に含まれるト ランスフォーミング増殖因子 $\beta$ などの分化阻害因子に よって, 筋芽細胞から筋管細胞への分化が抑制されて いる(28)。このことから, 筋管細胞への分化誘導は, 低濃度（例. 2\%）の FBS やゥマ血清（HS）（27, 29）, もしくは，成長因子（例. $10 \mu \mathrm{g} \mathrm{mL} \mathrm{m}^{-1}$ ウシインスリン） （30）のみを添加した液体培地に置換することによっ て行われている，後述するが，インスリンによるグル コース取り込み促進は, 筋管細胞では認められるもの の, 筋芽細胞では, GLUT1 による基礎グルコース取り 込みにマスクされて観察されない（されにくい）こと から，筋芽細胞を筋管細胞へ高度に分化させる必要が ある。本研究では, インスリンが筋形成促進作用を有 すること(31) を利用して， $2 \% \mathrm{HS}$ と $10 \mu \mathrm{g} \mathrm{mL} \mathrm{m}^{-1}$ ヒト インスリンを添加した液体培地を用いて, 筋芽細胞か ら筋管細胞への分化誘導を行った(13).

\section{6. 筋管細胞の特徵}

筋芽細胞から筋管細胞へ分化する過程で, 細胞の形 態や遺伝子発現などが変化する $(32)$. まず, 筋芽細胞 同士が融合し，巨大な筋管細胞を形成するため, 単核
性の筋芽細胞が多核性の筋管細胞となる。また，一部 の多核性筋管細胞は, 自発性収縮を示す。ささらに, 筋 芽細胞から筋管細胞への分化は, MyoD や Myogenin などの転写制御因子群の発現誘導カスケードによって 制御されているため, 転写制御因子の遺伝子発現が変 動する．例えば，MyoD は，筋芽細胞の融合を促進さ せる遺伝子であることから，分化初期の段階で，その 発現が上昇する。一方, Myogenin は，筋管細胞の形 成を促進させる遺伝子であることから, 分化後期の段 階で，その発現が上昇する。本研究では，図 1 に示し たように, $2 \% \mathrm{HS}$ と $10 \mu \mathrm{g} \mathrm{mL} \mathrm{m}^{-1}$ ヒトインスリンを添 加した液体培地中で筋芽細胞を 7 日間培養することに よって, 上述の特徴を有する高度に分化した筋管細胞 を得ることに成功した(13)。なお，筋管細胞の自発性 収縮については，文献 13 の補足データとして, Web 上 (http://onlinelibrary.wiley.com/doi/10.1111/ bph.13406/abstract）で動画が公開されている.

\section{7. 筋管細胞におけるインスリンによる Aktの リン酸化応答の薬理学的特徵}

L6 筋管細胞に異なる濃度のインスリンを 5 分間処 置したところ，濃度依存的にAktの $\mathrm{Thr}^{308}$ 及び $\operatorname{Ser}^{473}$

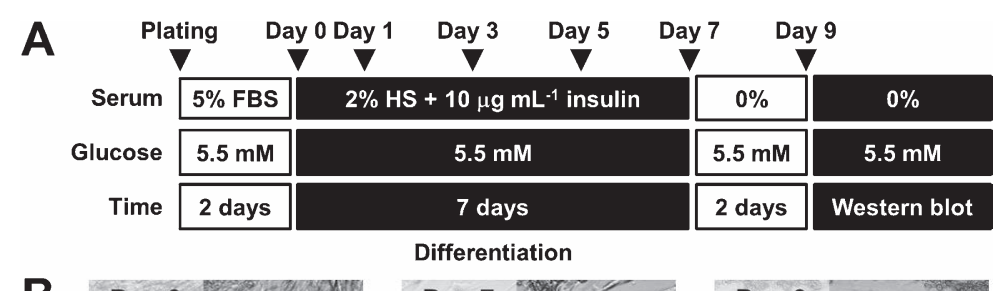

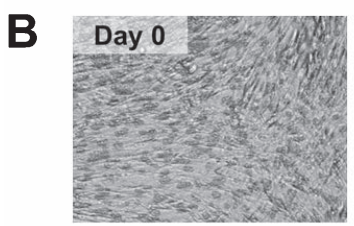

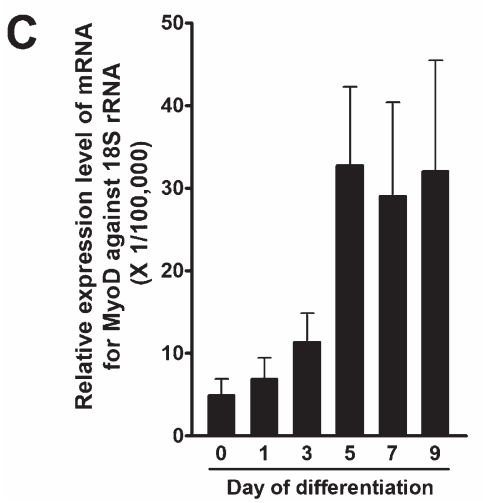


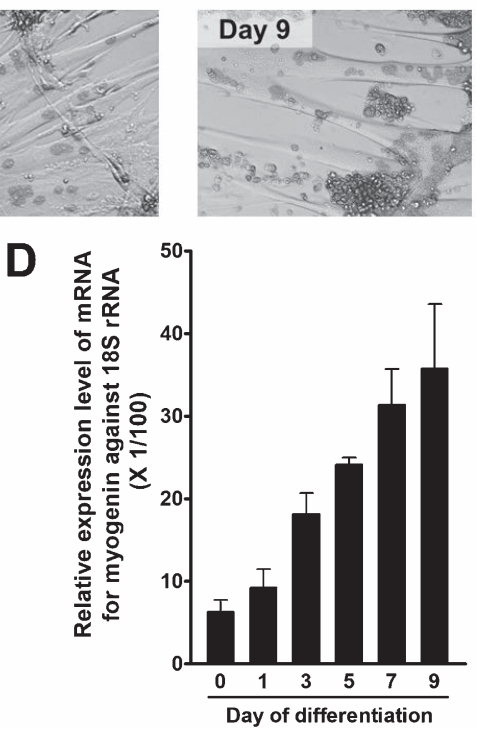

図 1 ラットL6 筋芽細胞から筋管細胞への分化

(A) 分化誘導のプロトコール. 2\%ウマ血清 (HS) と $10 \mu \mathrm{g} \mathrm{mL} \mathrm{m}^{-1}$ ヒトインスリンを添加した低グルコース液体培地で筋芽細胞を 7 日間培養し (2 日毎に培地交換)、筋管細胞への分化を誘導した. 分化誘導後, 無血清培地でさらに2 日間培養した後, Western blot 実験に供した. (B) 未分化の筋芽細胞（Day 0) と分化した筋管細胞（Day 7 及びDay 9）の位相差顕微鏡像. 核は, Hoechst 33342 を用して染色した. (C 及び D) 分化マーカ一遺伝子である MyoD (C) 及び myogenin (D) の mRNA 発現の経時变化. 各遺伝子発現量は, 内部標準遺伝子である18S rRNA の mRNA 発現量で補正した. グラフは, 5 例の平均值土標準誤差.（文献 13 より改変転載） 
のリン酸化レベルが上昇した（図 2A). 同様に, $300 \mathrm{nM}$ インスリンによるAkt のリン酸化応答の経時 変化を検討したところ, Akt の $\mathrm{Thr}^{308}$ 及び $\mathrm{Ser}^{473}$ のリ ン酸化レベルは, 刺激後 10 分もしくは 15 分の時点で 最大に達し, 30 分以降から減少に転じた（図 2B)。し かしながら, 刺激後 30 分及び 60 分の時点において, Akt の $\mathrm{Thr}^{308}$ 及び $\operatorname{Ser}^{473}$ のリン酸化レベルは, 最大応 答の約 $75 \%$ を維持しており, インスリンによる Akt の リン酸化応答は，持続性であることが明らかになった。

前述したように，インスリンによるAktのリン酸化 応答は，PI3Kを介していると考えられている．PI3Kの 関与を薬理学的に証明するため, 古くから wortmannin やLY294002 などの PI3K阻害薬が用いられてきた。し かしながら, wortmannin や LY294002 は, PI3K 以外 のキナーゼも抑制することから(33), 本研究では, LY294002 の他に, PI3K に対する選択性が極めて高い GSK2126458(34）を用いた. $300 \mathrm{nM}$ インスリンを筋 管細胞に 5 分間処理した時に生じる Akt のリン酸化応 答は, $10 \mathrm{nM}$ GSK2126458 及び $50 \mu \mathrm{M}$ LY294002 の前 処置によって，ほぼ完全に抑制された（図 2C). 以上 の結果から，筋管細胞に拝いて，インスリンが, PI $3 \mathrm{~K}$ の活性化を介して, Akt の $\mathrm{Thr}^{308}$ 及び $\mathrm{Ser}^{473}$ のリン酸
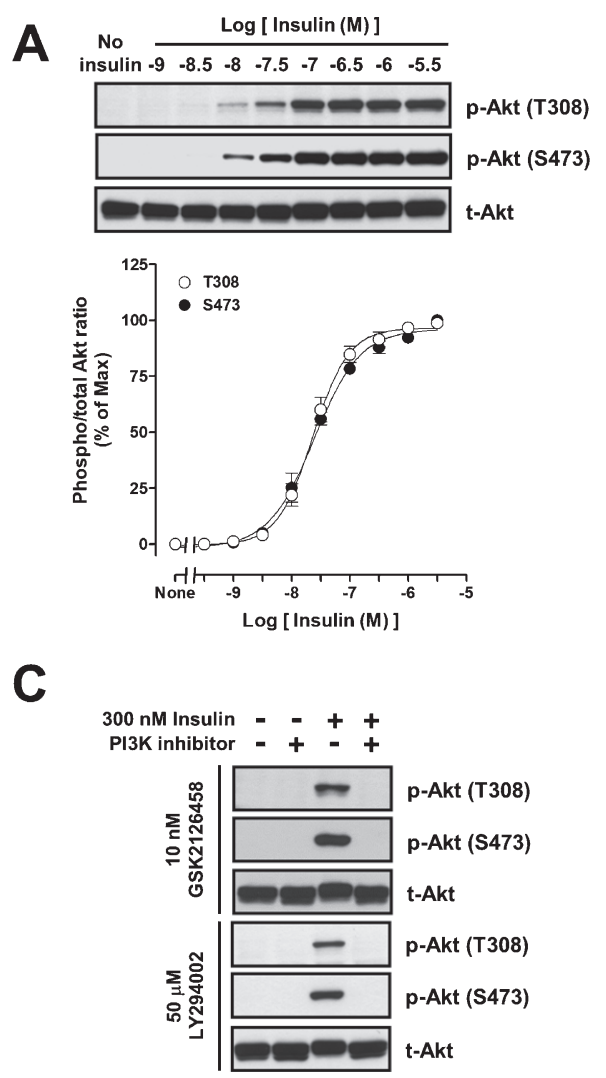

化を促進することが確認された.

\section{8. 筋管細胞におけるインスリンによる Akt の リン酸化応答に対する ET-1 の抑制作用}

筋芽細胞から筋管細胞への分化は, 細胞外シグナル 調節キナーゼ $(\mathrm{ERK}) 1 / 2$ によって抑制されることが 知られている (35). 筆者らは, L6 筋芽細胞において, ET-1 が, 血小板由来成長因子受容体のトランス活性 化を介して，ERK1/2を活性化することを明らかにし， ET-1による筋芽細胞の分化阻害がインスリン抵抗性 の一因になる可能性を示唆した (36). 本研究では, 筋 管細胞におけるインスリンシグナルに対する ET-1 の 作用を解析した。

L6 筋管細胞に $100 \mathrm{nM}$ インスリンを 60 分間処理す ると, Akt の $\mathrm{Thr}^{308}$ 及び $\mathrm{Ser}^{473}$ のリン酸化レベルが上 昇し, このリン酸化応答は, $30 \mathrm{nM} \mathrm{ET-1} の$ 後処理に よって有意に抑制された（図 3)。インスリンによる Akt のリン酸化応答に対する ET-1 の抑制作用は, 選択 的 $\mathrm{ET}_{\mathrm{A}} \mathrm{R}$ 遮断薬である $\mathrm{BQ}-123$ 及び選択的 $\mathrm{G}_{\mathrm{q} / 11}$ タンパ ク質阻害薬である YM-254890の前処理によって解除 されたが（図 3)，選択的 $\mathrm{ET}_{\mathrm{B}} \mathrm{R}$ 遮断薬である $\mathrm{BQ}-788$ (図 3) や選択的 $\mathrm{G}_{\mathrm{i}}$ タンパク質阻害薬である百日咳毒素
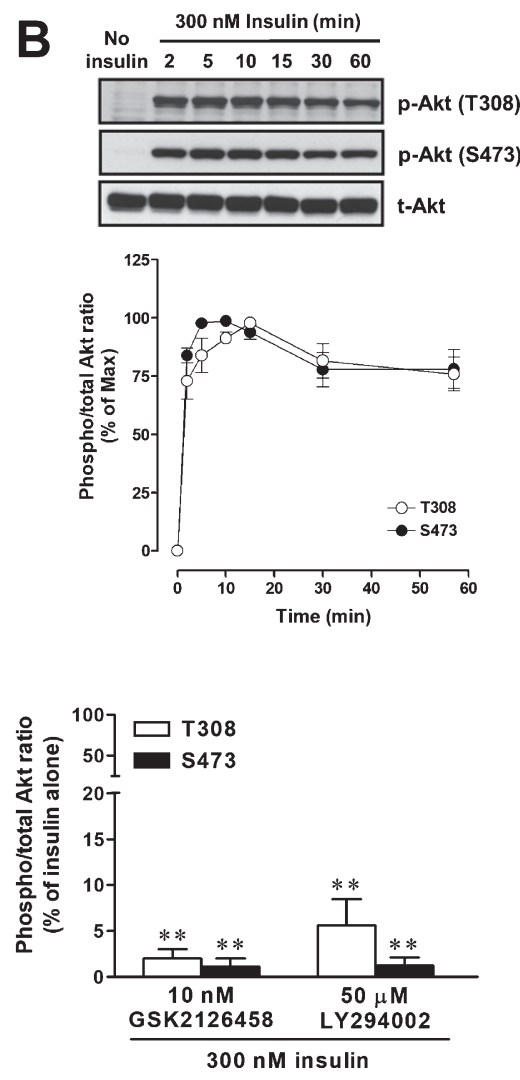

図 2 ラットL6 筋管細胞におけるインスリンによる Akt のリン酸化応答の薬理学的特徴

(A) インスリンによるAkt のリン酸化応答の濃度一反応関係. インスリンの処理時間は全て 5 分間. (B) $300 \mathrm{nM}$ インスリンよるAktのリ ン酸化応答の経時変化. (C) $300 \mathrm{nM}$ インスリンの 5 分間処置による Akt のリン酸化応答に対する PI3K 阻害薬 (GSK2126458 及び LY294002) の影響. グラフは, 6 例の平均值土標準誤差. ${ }^{* *} P<0.01$ (300 nM インスリン単独との比較). (文献 13 より改変転載) 
(13), $\mathrm{G}_{\mathrm{s}}$ タンパク質阻害薬である $\mathrm{NF} 449$ (13) の前処 置では影響を受けなかった。これらのことから，ET-1 は, $\mathrm{ET}_{\mathrm{A}} \mathrm{R}$ 及び $\mathrm{ET}_{\mathrm{A}} \mathrm{R}$ と共役する $\mathrm{G}_{\mathrm{q} / 11}$ タンパク質の活 性化を介して，インスリンシグナルを抑制していると 考えられた。

$\mathrm{G}_{\mathrm{q} / 11}$ タンパク質と共役する $\mathrm{ET}_{\mathrm{A}} \mathrm{R} に \mathrm{ET}-1$ が結合する と, 三量体 $\mathrm{G}$ タンパク質を構成する $\mathrm{G}_{\alpha}$ と $\mathrm{G}_{\beta \gamma}$ が ET-1 結合型 $\mathrm{ET}_{\mathrm{A}} \mathrm{R}$ から解離する。 GRK2 の $\mathrm{C}$ 末端領域には, $\mathrm{G}_{\beta \gamma}$ と結合するプレクストリン相同ドメインが存在す るため(24), GRK2 は, 細胞膜近傍の $\mathrm{G}_{\beta \gamma}$ ヘリクルー トされ，ET-1 結合型 $\mathrm{ET}_{\mathrm{A}} \mathrm{R}$ をリン酸化（不活化）する. さらに, 細胞膜近傍に集積した GRK2 は, Akt と結合 し, Aktの活性化を阻害することが血管内皮細胞にお いて報告されている(26)，そこで，骨格筋細胞におい て，インスリンによるAktのリン酸化応答に対する ET-1 の抑制作用に, GRK2 が関与しているのか明らか にするため， siRNAによる GRK2 発現抑制の影響を検 討した. 図 4 に示したように,コントール siRNAを導 入した筋管細胞において, ET-1によるインスリンシ グナルの抑制が観察されたものの, siRNAを用いて GRK2 発現を抑制した筋管細胞においては, ET-1 の抑 制作用がほぼ消失した。これらの結果は，ET-1が GRK2 を介して，インスリンによるAktのリン酸化応答 を抑制していることを示している.

\section{9.インスリンによるグルコース取り込み促進 に対する ET-1 の抑制作用}

上述の Western blot解析から，筋管細胞において， インスリンによって PI $3 \mathrm{~K}$ 依存性に Akt の $\mathrm{Thr}^{308}$ 及び $\operatorname{Ser}^{473}$ のリン酸化レベルが上昇し，このリン酸化応答 は ET-1によって抑制されることが明らかになった。 これらの細胞応答が，グルコース取り込みに反映され ているのか確認するため, トリチウム $\left({ }^{3} \mathrm{H}\right)$ で標識さ れた2-デオキシ-D-グルコース $\left(\left[{ }^{3} \mathrm{H}\right] 2-\mathrm{DG}\right)$ を用いた グルコース取り込み実験を行った。2-DGは，グル コースの2-ヒドロキシル基が水素原子に置換された グルコース誘導体であり，グルコースと同様に細胞内 へ取り込まれるが，解糖系による代謝を受けないため， 細胞内に蓄積する。

筋芽細胞や筋管細胞には, グルコースの基礎取り込 みを担う GLUT1 とインスリンによるグルコース取り 込みを担う GLUT4 が発現しているが，分化の進行に 伴って, GLUT1 発現量は経時的に減少し, GLUT4 発 現量は増加する(37-38). 即ち, 筋芽細胞から筋管細 胞へ分化する過程で, グルコースの基礎取り込みは減 少し，インスリンによるグルコース取り込みは増大す る(37-38)，従って，高度に分化した筋管細胞では， GLUT1 発現量に対する GLUT4 発現量の比率 (GLUT4/ GLUT1 発現比) が高くなるため, グルコース取り込み

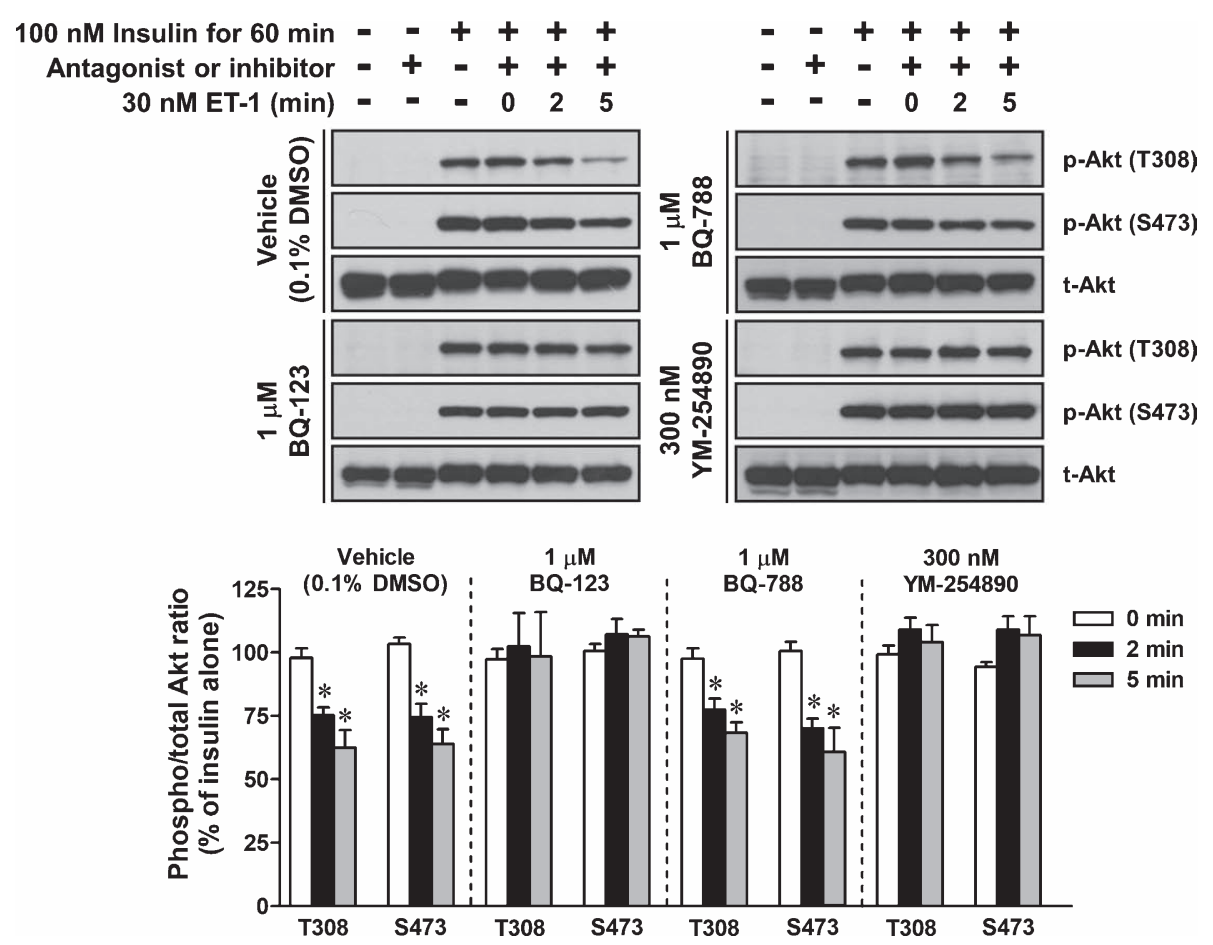

図 3 ET-1 によるインスリン誘発性 Akt リン酸化応答の抑制に対する $B Q-123$ (選択的 $E T_{A} R$ 遮断薬), $B Q-788$ (選択的 $E T_{B} R$ 遮断 薬) 及び $Y M-254890$ (選択的 $G_{q / 11}$ タンパク質阻害薬) の影響

BQ-123, BQ-788 及び YM-254890 は, インスリン刺激を行う 30 分前に処理した. ET-1 は, インスリン刺激を終了する2 分前及び5 分前に添加 した. グラフは, 6 例の平均值士標準誤差. ${ }^{*} P<0.05$ (100 nM インスリン単独との比較). (文献 13 より改変転載) 



図 4 ET-1 によるインスリン誘発性 Akt リン酸化応答の抑制に対する siRNA による GRK2 発現抑制の影響

SiRNA をトランスフェクションしてから96 時間後にインスリン刺激を行った. ET-1 は, インスリン刺激を終了する2 分前及び5 分前に添加 した. グラフは, 6 例の平均值士標準誤差. ${ }^{*} P<0.05$ (100 nM インスリン単独との比較). ${ }^{*} P<0.05$ (control siRNA 処理細胞との比較). (文 献 13 より改変転載)

\begin{tabular}{|c|c|c|c|c|c|}
\hline \multicolumn{2}{|c|}{$\stackrel{\text { Plating }}{\nabla}$} & $y^{2}$ & \multirow[b]{2}{*}{$0 \%$} & \multirow[b]{2}{*}{$0 \%$} & \multirow{2}{*}{$0 \%$} \\
\hline Serum & $5 \% \mathrm{FBS}$ & $2 \% \mathrm{HS}+10 \mu \mathrm{g} \mathrm{mL}^{-1}$ insulin & & & \\
\hline Glucose & $5.5 \mathrm{mM}$ & $5.5 \mathrm{mM}$ & $5.5 \mathrm{mM}$ & $1.0 \mathrm{mM}$ & $1.0 \mathrm{mM}$ \\
\hline \multirow[t]{2}{*}{ Time } & 2 days & 7 days & 3 days & $30 \mathrm{~min}$ & Glucose uptake assay \\
\hline & & entiation & in $+\left[{ }^{3} \mathrm{H}\right]$ & G (+ ET-1 & $2 \mathrm{~h}$ \\
\hline
\end{tabular}


図 5 ラット L6 筋管細胞におけるインスリンによる $\left[{ }^{3} \mathrm{H}\right] 2-D G$ 取り込み促進の薬理学的特徵

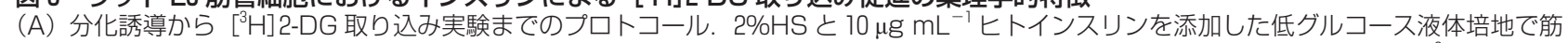
芽細胞を7日間培養し (2 日毎に培地交換), 筋管細胞への分化を誘導した. 分化誘導後, 無血清培地でさらに3 日間培養した後, [ $\left.{ }^{3} H\right] 2-D G$ 取 り込み実験に供した。（B）インスリンによる $\left.{ }^{3} H\right] 2-D G$ 取り込み促進に対する PI3K 阻害薬（GSK2126458 及び LY294002）の影響. (C) イン スリンによる $\left.{ }^{3} \mathrm{H}\right]$ 2-DG 取り込み促進に対する $\mathrm{ET}$-1 の影響. グラフは， 8 例の平均值土標準誤差. ${ }^{*} P<0.05,{ }^{* *} P<0.01 （$ インスリン単独との 比較). (文献 13 より改变転載)

実験のバックグラウンドとなる GLUT1 によるグル コースの基礎取り込みが減少し，インスリンによる GLUT4 を介したグルコース取り込みの評価が容易に なる.

図 5A に示したように, $\left[{ }^{3} \mathrm{H}\right] 2-\mathrm{DG}$ 取り 込み実験の場 合, 7 日間の分化誘導後, 無血清培地でさらに 3 日間 培養した。 この無血清培地を用いた培養によって, 血
清飢餓に抵抗性を示す筋管細胞の基礎的な $\left[{ }^{3} \mathrm{H}\right] 2-\mathrm{DG}$ 取り达みが経時的に減少し(データは示さず), インス リンによる $\left[{ }^{3} \mathrm{H}\right] 2-\mathrm{DG}$ 取り込み促進が観察しやすくな る. $100 \mathrm{nM}$ インスリンで筋管細胞を 2 時間刺激した ところ， $\left[{ }^{3} \mathrm{H}\right] 2-\mathrm{DG}$ 取り込み速度は，およそ $150 \%$ 上昇 し，インスリンの $\left.{ }^{3} \mathrm{H}\right] 2-\mathrm{DG}$ 取り込み促進作用は, PI $3 \mathrm{~K}$ 阻害薬である 10 nM GSK2126458 及び $50 \mu \mathrm{M}$ LY294002 

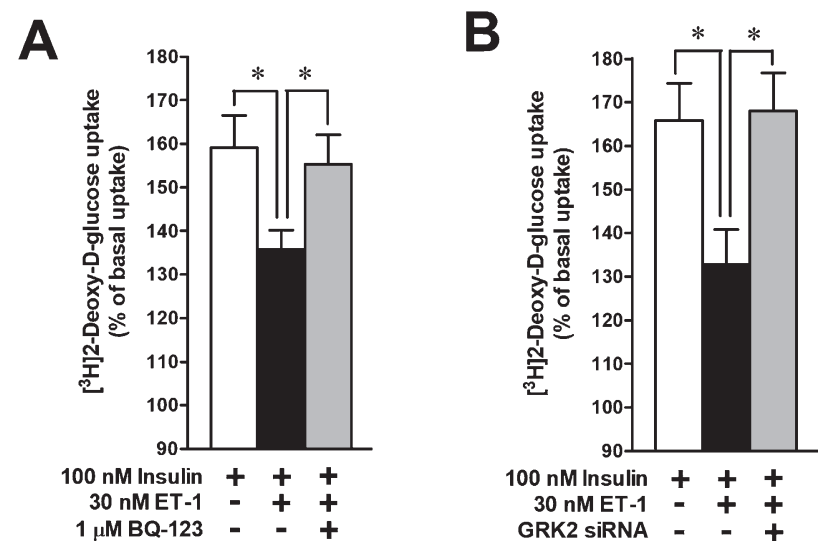

図 6 ET-1 によるインスリン誘発性 $\left.{ }^{3} \mathrm{H}\right] 2-D G$ 取り込み促進の抑 制に対する $B Q-123$ (選択的 $E_{\mathrm{A}} \mathrm{R}$ 遮断薬) 及び siRNA による GRK2 発現抑制の影響

BQ-123は, インスリン刺激を行う30 分前に処理した. SiRNAをトラ ンスフェクションしてから 96 時間後にインスリン刺激を行った. ET-1 は, インスリンと同時に処理した. グラフは, 8 例の平均值士標準誤差 ${ }^{*} P<0.05$. (文献 13 より改変転載)

の前処置によって抑制された（図 5B). インスリンに よる $\left[{ }^{3} \mathrm{H}\right] 2-\mathrm{DG}$ 取り込み速度の上昇は, 濃度依存的で あり,インスリンの濃度反応曲線から得られた $\mathrm{pEC}_{50}$ は $8.08 \pm 0.11$, 最大反応は $155 \pm 5 \%$ であった（図 5C).

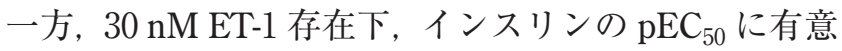
な変化は認められなかったものの，最大反応は非競合 的に抑制された（図 $5 \mathrm{C}$ ).

インスリンによる $\left[{ }^{3} \mathrm{H}\right] 2-\mathrm{DG}$ 取り込み促進に対する ET-1 の抑制作用は, Aktのリン酸化応答と同様に, 選択的 $\mathrm{ET}_{\mathrm{A}} \mathrm{R}$ 遮断薬である $\mathrm{BQ}-123$ の前処理（図 6A） 及び siRNAを用いた GRK2 の発現抑制（図 6B）によっ て解除された。これらのことから， $\mathrm{ET}_{\mathrm{A}} \mathrm{R}$ 及び $\mathrm{GRK} 2$ が，ET-1によるインスリンシグナルの抑制に関与し ていることが明らかになった。



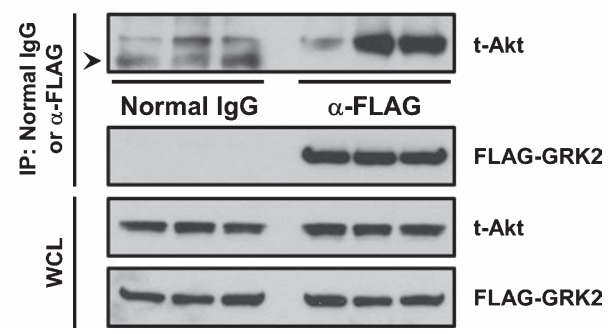

図 7 ラットL6 筋管細胞における FLAG 融合 GRK2 と内在性 Akt との分子間相互作用に対する ET-1 の影響

IP: 免疫沈降に用いた抗体. WCL : 全細胞抽出液. 内在性 Akt 及び FLAG 融合 GRK2 の検出に用いた一次抗体は, それぞれ, 抗 total Akt 抗体及び抗 FLAG-HRP 抗体である. 矢頭は, コントロール抗体 (normal mouse lgG) を用いた際に検出された非特異的シグナルを指 す. (文献 13 より改変転載)

\section{ET-1 による GRK2-Akt 相互作用の増強}

ET-1 によるインスリンシグナルの抑制機序として, GRK2 と Akt の相互作用が関与しているのか明らかに するため，免疫共沈降法を用いて検討した．まず，レ トロウィルスを用いて, FLAG 融合 GRK2 タンパク質 （FLAG-GRK2）を安定的に発現する筋芽細胞を作製し， この筋芽細胞を筋管細胞へ分化させた，FLAG-GRK2 と共沈降した内在性 Akt 量を解析したところ, $30 \mathrm{nM}$ ET-1 刺激によって, FLAG-GRK2 と結合する内在性 Akt 量が増加した。このことから, ET-1 は, GRK2 と Akt との分子間相互作用を促進することによって, イ ンスリンシグナルを抑制している可能性が示唆された.

\section{1. おわりに}

ET-1 による骨格筋細胞でのインスリンシグナルの 抑制機序を図 8 にまとめた。インスリンは, PI $3 \mathrm{~K} の$ 活性化を介して, Aktのリン酸化レベルを上昇させ,

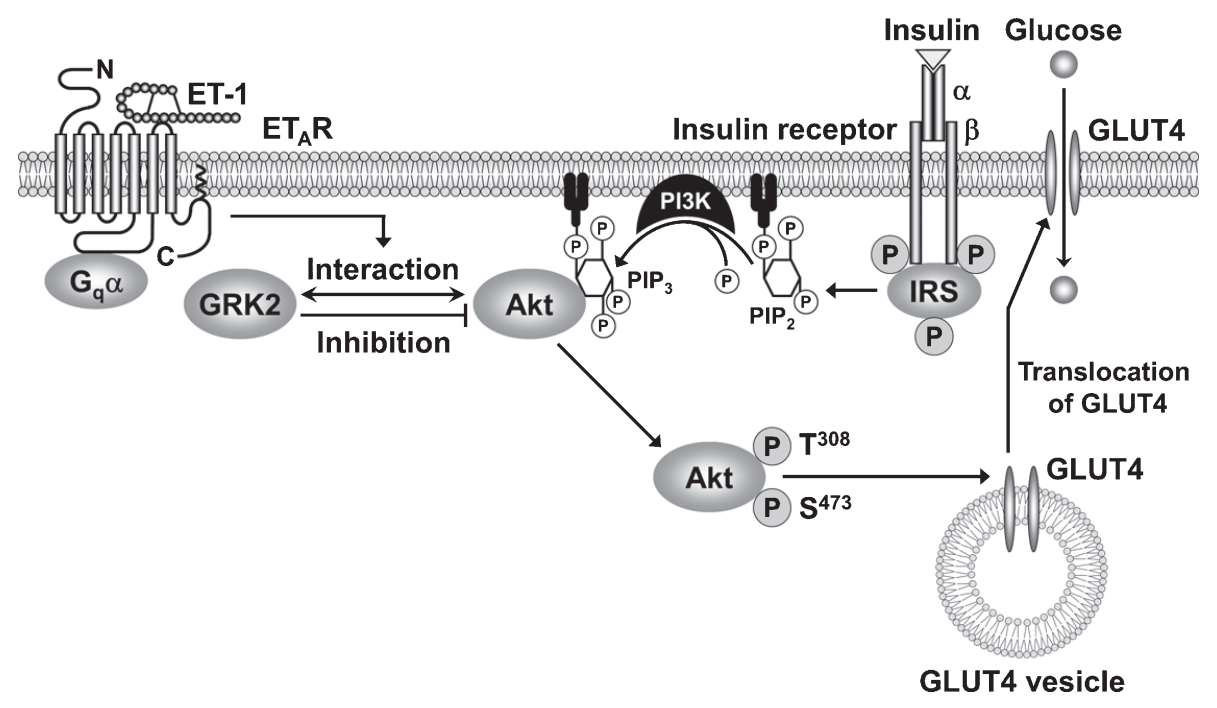


グルコース取り込みを促進する。これに対して，ET-1 は, $\mathrm{ET}_{\mathrm{A}} \mathrm{R}$ と $\mathrm{G}_{\mathrm{q} / 11}$ タンパク質の活性化, ならびに, GRK2 と Aktの分子間相互作用の増強を介して, イン スリンによる Aktのリン酸化応答及びグルコース取り 达み促進を抑制する。 今後, $\mathrm{ET}_{\mathrm{A}} \mathrm{R}$ や $\mathrm{GRK} 2$ をター ゲットにしたインスリン抵抗性の治療戦略の開発が期 待される。

著者の利益相反：開示すべき利益相反はない.

\section{文献}

1) Yanagisawa M, et al. Nature. 1988;332:411-415.

2) Pernow J, et al. Life Sci. 2012;91:507-516.

3) Rodríguez-Pascual F, et al. Pharmacol Res. 2011;63:463-472.

4) Horinouchi T, et al. 日薬理誌. 2016;148:231-238.

5) Touyz RM, et al. Can J Physiol Pharmacol. 2003;81:533-541.

6) Lerman A, et al. N Engl J Med. 1991;325:997-1001.

7) Takahashi K, et al. Diabetologia. 1990;33:306-310.

8) Ferri C, et al. Diabetes. 1995;44:431-436.

9) Horinouchi T, et al. J Pharmacol Sci. 2013;123:85-101.

10) Rubin LJ. Life Sci. 2012;91:517-521.

11) Shemyakin A, et al. Diabetes. 2011;60:2061-2067.

12) Usui I, et al. Mol Endocrinol. 2005;19:2760-2768.

13) Horinouchi T, et al. Br J Pharmacol. 2016;173:1018-1032.
14) DeFronzo RA. Diabetes. 1988;37:667-687.

15) Schalin-Jäntti C, et al. Diabetologia. 1994;37:401-407.

16) Leto D, et al. Nat Rev Mol Cell Biol. 2012;13:383-396.

17) Shisheva A. Am J Physiol Endocrinol Metab. 2008;293:E536E544.

18) Laplante M, et al. Cell. 2012;149:274-293.

19) Sarbassov DD, et al. Science. 2005;307:1098-1101.

20) Kubota T, et al. Cell Metab. 2011;13:294-307.

21) Goodpaster BH, et al. Diabetes. 2014;63:1058-1068.

22) Ottosson-Seeberger A, et al. Acta Physiol Scand. 1997;161:211220.

23) Reiter E, et al. Trends Endocrinol Metab. 2006;17:159-165.

24) Evron T, et al. Trends Pharmacol Sci. 2012;33:154-164.

25) Usui I, et al. EMBO J. 2004;23:2821-2829.

26) Liu S, et al. Nat Med. 2005;11:952-958.

27) Nevzorova J, et al. Br J Pharmacol. 2002;137:9-18.

28) Heino J, et al. J Biol Chem. 1990;265:10181-10184.

29) Ruest LB, et al. J Biol Chem. 2002;277:5418-5425.

30) Jin P, et al. J Biol Chem. 1991;266:1245-1249.

31) Wu YJ, et al. PLoS One. 2014;9:e88450.

32) Bentzinger CF, et al. Cold Spring Harb Perspect Biol. 2012;4:ID a008342.

33) Davies SP, et al. Biochem J. 2000;351:95-105.

34) Knight SD, et al. ACS Med Chem Lett. 2010;1:39-43.

35) Minami M, et al. Mol Biol Cell. 2011;22:3508-3519.

36) Harada T, et al. Life Sci. 2014;104:24-31.

37) Mitsumoto Y, et al. Biochem Biophys Res Commun. 1991;175:652-659.

38) Mitsumoto Y, et al. J Biol Chem. 1992;267:4957-4962.

\title{
Molecular mechanism for ET-1-induced insulin resistance in skeletal muscle cells
}

\author{
Takahiro Horinouchi $^{1)}$, Yuichi Mazaki ${ }^{1)}$, Koji Terada ${ }^{2)}$, Soichi Miwa ${ }^{1)}$ \\ ${ }^{1)}$ Department of Cellular Pharmacology, Graduate School of Medicine, Hokkaido University \\ ${ }^{2)}$ Department of Biochemistry and Molecular Biology, Shiga University of Medical Science
}

\begin{abstract}
Insulin resistance is a condition where the sensitivity to insulin of the tissues expressing insulin receptor (InsR) is decreased due to a functional disturbance of InsR-mediated intracellular signaling. Insulin promotes the entry of glucose into the tissues and skeletal muscle is the most important tissue responsible for the insulin's action of decreasing blood glucose levels. Endothelin-1 (ET-1), a potent vasoconstrictor and proinflammatory peptide, induces insulin resistance through a direct action on skeletal muscle. However, the signaling pathways of ET-1-induced insulin resistance in skeletal muscle remain unclear. Here we show molecular mechanism underlying the inhibitory effect of ET-1 on insulin-stimulated Akt phosphorylation and glucose uptake in myotubes of rat L6 skeletal muscle cell line. mRNA expression levels of differentiation marker genes, MyoD and myogenin, were increased during L6 myoblasts differentiation into myotubes. Some of myotubes possessed the ability to spontaneously contract. In myotubes, insulin promoted Akt phosphorylation at $\mathrm{Thr}^{308}$ and $\mathrm{Ser}^{473}$, and $\left[{ }^{3} \mathrm{H}\right]$-labelled 2-deoxy-D-glucose $\left(\left[{ }^{3} \mathrm{H}\right] 2-\mathrm{DG}\right)$ uptake. The insulinfacilitated Akt phosphorylation and $\left.{ }^{3} \mathrm{H}\right] 2-\mathrm{DG}$ uptake were inhibited by ET-1. The inhibitory effect of ET-1 was counteracted by blockade of ET type A receptor $\left(\mathrm{ET}_{\mathrm{A}} \mathrm{R}\right)$, inhibition of $\mathrm{G}_{\mathrm{q} / 11}$ protein, and siRNA knockdown of G protein-coupled receptor kinase 2 (GRK2). The exogenously overexpressed GRK2 directly bound to endogenous Akt and their association was facilitated by ET-1. In summary, activation of $\mathrm{ET}_{\mathrm{A}} \mathrm{R}$ with ET-1 inhibits insulin-induced Akt phosphorylation and $\left[{ }^{3} \mathrm{H}\right] 2-\mathrm{DG}$ uptake in a $\mathrm{G}_{\mathrm{q} / 11}$ protein- and GRK2dependent manner in skeletal muscle. These findings indicate that $\mathrm{ET}_{\mathrm{A}} \mathrm{R}$ and GRK2 are potential targets for insulin resistance.
\end{abstract}

